\title{
Spray-Drying of Passion Fruit Juice Using Lactose- Maltodextrin Blends as the Support Material
}

\author{
Ruiz Cabrera Miguel Angel ${ }^{1 *}$, Lucía Carolina Espinosa-Muñoz ${ }^{1}$, Carlos Aviles-Aviles ${ }^{1}$, \\ Raúl González-García ${ }^{1}$, Mario Moscosa-Santillán ${ }^{1}$, Alicia Grajales-Lagunes ${ }^{1}$ and Miguel \\ Abud-Archila ${ }^{2}$

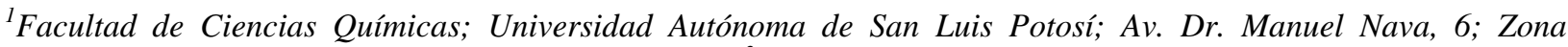 \\ Universitaria; C.P. 78210; San Luis Potosí - México. ${ }^{2}$ División de Estudios de Posgrado e Investigación; Instituto \\ Tecnológico de Tuxtla Gutiérrez; Carretera Panamericana km. 1080; C.P. 29050; Tuxtla Gutiérrez Chiapas - \\ México
}

\begin{abstract}
The objective of this study was to assess the effectiveness of the blends with different levels of lactose-maltodextrin $(8: 5,10: 5$, and $12: 5 \% \mathrm{w} / \mathrm{v})$ during the spray-drying of the passion fruit juice. The drying was carried out in a laboratory spray dryer (Pulvis GB 22 model) at two inlet air temperatures (180 and $190{ }^{\circ} \mathrm{C}$ ), and two air pressures $(0.10$ and $0.20 \mathrm{MPa})$. The moisture content, hygroscopicity and vitamin $C$ retention were evaluated in the powder obtained. Response surface plots $(p<0.05)$ showed that the lowest values of the moisture content and hygroscopicity were reached in the temperature range of $188-190{ }^{\circ} \mathrm{C}$ and at $12: 5 \%(\mathrm{w} / \mathrm{v})$ concentration of lactose-maltodextrin; the best vitamin $\mathrm{C}$ retention level occurred at $180^{\circ} \mathrm{C}$ and $0.2 \mathrm{MPa}$.
\end{abstract}

Key words: Passion fruit juice, spray-drying, vitamin $\mathrm{C}$ retention, hygroscopicity

\section{INTRODUCTION}

Spray-drying is defined as the transformation of liquid state feed into a dried particulate form. This is achieved by atomizing the fluid into a drying chamber, where the liquid droplets are passed through a hot-air stream (Barbosa-Cánovas et al., 2005; Masters, 1991a). The heat and mass transfer during the drying occurs rapidly between the air and vapour films surrounding the droplet at the saturation temperature. This technique, consequently, is suitable for the heat-sensitive products (Mermelstein, 2001). This type of drying process is widely used in the large-scale industry to produce the milk powders, instantaneous coffee and fruit juice powders, as well as for the encapsulation of the active components (BarbosaCánovas et al., 2005; Masters, 1991a). The spraydrying can also be used to process the passion fruit juice (Passiflora edulis $v$. flavicarpa) and obtain a powdered product, which is stable and suitable for storage and transportation. This juice, highly acidic and with a characteristic, intense flavor, constitutes a good source of niacin, riboflavin and vitamins C and A (Chan et al., 1972).

Currently, there is a great interest in exporting this crop to Europe, where it is becoming a popular luxury fruit. Among the main exporter countries are Ecuador, Colombia, Peru, Brazil and Indonesia

\footnotetext{
* Author for correspondence: mruiz@uaslp.mx
} 
(Vera et al., 2003). Mexico has participated only occasionally in the international market selling 3 ton of concentrated juice to the United States (Schwentesius and Gómez-Cruz, 1998). Passion fruit cannot be stored for more than eight days at $25{ }^{\circ} \mathrm{C}$, because decay will take place after that span (Flores-Novelo, 2000). A frequent solution to this problem is the processing and freezing of the fruit pulp and juice (either natural or concentrated) which can be later on used for flavouring various drinks or for blending with other kinds of the juices. In the literature, different methods of the concentration such as the membrane processes (Cardoso-Pereira et al., 2002), osmotic evaporation (Vaillant et al., 2001), and flash vacuum-expansion (Brat et al., 2001) have been proposed for processing the passion fruit juice.

The main problem during the spray-drying of the sugar-rich foods like the fruit juices is their thermoplastic and hygroscopic behavior (Truong et al., 2005; Goula and Adamopoulos, 2005). All the fruits contain the sugars of low glass transition temperature $\left(\mathrm{T}_{\mathrm{g}}\right)$ (saccharose, glucose and fructose) and during drying, they may either remain as the syrup or stick to the drier chamber walls. The juice of the passion fruit is very difficult to be spray-dried, because the total sugar is composed of fructose $(45 \%)$ glucose $(46 \%)$ and sucrose (9\%) (Vera et al., 2003) and their $\mathrm{T}_{\mathrm{g}}$ values are $5{ }^{\circ} \mathrm{C}, 31^{\circ} \mathrm{C}$ and $62{ }^{\circ} \mathrm{C}$, respectively (Bhandari and Howes, 1999).

Some additives such as the starch, arabic gum, and maltodextrins are commonly used as the support materials to increase the $\mathrm{T}_{\mathrm{g}}$ of the products during the spray-drying (Truong et al., 2005; Jaya and Das, 2004). The amount of these carrier agents depends on the fruit in question and ranges from 20 to $60 \%(\mathrm{w} / \mathrm{v})$ have been reported in the literature (Masters, 1991a). However, the quantity of the drying aids is limited by the organoleptic properties of the final product (Truong et al., 2005). Some authors (Jaya and Das, 2004; Krishnan et al., 2005) have proposed the combination of maltodextrin, arabic gum, modified starch, and anticaking agents like glycerol monostearate and tricalcium phosphate as yet another alternative. Studies on the utilization of maltodextrin blended with high glass transition temperature disaccharides such as lactose $\left(\mathrm{T}_{\mathrm{g}}=\right.$ $101{ }^{\circ} \mathrm{C}$ ) are, nonetheless, scarce. For example, during the spray-drying of the dairy products, a free-flowing powder could be obtained sometimes, since several physicochemical properties are directly or indirectly related to the $T_{g}$ of this disaccharide (Roos, 2002). Due to the low sweetness of lactose, food manufacturers add bigger amounts of the solids without excessive sweetness in the preparation of the balanced infant formulae.

This study aimed to assess the performance of a lactose-maltodextrin mixture acting as a carrier agent in the spray-drying of the passion fruit juice, under various operation conditions in order to obtain a powdered product.

\section{MATERIALS AND METHODS}

\section{Passion fruit and extraction of juice}

Fresh passion fruits were collected from a plantation located in Chimalaco, San Luis Potosí, México. The fruits were washed and cut into halves, discarding the skins and keeping only the pulp, which was treated with the enzymatic method proposed by Rodriguez-Hernández et al., (2005) to obtain the juice suitable for atomization. The juice was stored at $-14{ }^{\circ} \mathrm{C}$ and later defrosted at the room temperature right before the experiment.

\section{Sample preparation and spray drying}

The commercial lactose (Empresas Vhiler, S.A. de C.V.) and maltodextrin (10 DE) (AmidexProquimposa) were used as the carrier agents. The blends with different levels of the lactosemaltodextrin $(8: 5,10: 5,12: 5 \% \mathrm{w} / \mathrm{v})$ were used to prepare the juice using a shear mixer (Ika-UltraTurrax ${ }^{\circledR}$ T25 Basic) at $3000 \mathrm{rpm}$ for $5 \mathrm{~min}$. The drying was performed in a laboratory spray dryer (Pulvis GB 22 model, YAMATO), using a feed flow rate of $20 \mathrm{ml} / \mathrm{min}$ and an air flow rate of 0.43 $\mathrm{m}^{3} / \mathrm{min}$. The inlet air temperatures of 180 and 190 ${ }^{\circ} \mathrm{C}$ with the air pressures of 0.10 and $0.20 \mathrm{MPa}$ were applied. A D-optimal experimental design with two center points and one replicate for each experimental condition was used. A total of 26 runs were conducted (Table 1). The moisture content, hygroscopicity and vitamin $\mathrm{C}$ retention, taken as the dependent variables, were evaluated for each run.

\section{Analysis of powders}

The moisture content was measured gravimetrically by drying approximately $2 \mathrm{~g}$ of the powder in a vacuum oven at $70{ }^{\circ} \mathrm{C}$ under a pressure of $70 \mathrm{kPa}$, for $24 \mathrm{~h}$. The stability of the 
vitamin $\mathrm{C}$ during the spray-drying was evaluated by the titration using 2,6-dichloro-indophenol as described in the Official Methods of Analysis (AOAC, 1990). For the hygroscopicity, about $1 \mathrm{~g}$ of powder was placed in a hermetic glass jar containing a saturated solution of $\mathrm{Na}_{2} \mathrm{SO}_{4}$ to establish a relative humidity of $81 \%$ (Cai and Corke, 2000). After keeping the sample at $25{ }^{\circ} \mathrm{C}$ for a week, the hygroscopic moisture (\%) was calculated using equation (1) (Jaya and Das, 2004):

$$
\operatorname{Hygroscopicity~}(\%)=\frac{\mathrm{b} / \mathrm{a}+\mathrm{Wi}}{1+\mathrm{b} / \mathrm{a}}
$$

where a $(\mathrm{g})$ was the amount of the sample, Wi was the moisture content in the powder before the measurement and $\mathrm{b}(\mathrm{g})$ was the powder weight increase. All the measurements were made in three replicates.

\section{Statistical analysis}

A polynomial model was fitted to the experimental data to predict the dependent variable $Y$ (moisture content, hygroscopicity, vitamin $\mathrm{C}$ retention):

$$
\begin{aligned}
& Y=\beta_{o}+\beta_{1} T+\beta_{2} P+\beta_{3} C+\beta_{4} T^{2}+\beta_{5} P^{2}+ \\
& \beta_{6} C^{2}+\beta_{7} T P+\beta_{8} T C+\beta_{9} P C
\end{aligned}
$$

where $\beta_{i}(i=0,1, \ldots .9)$ represented the linear regression coefficients of the model; and T, P and $\mathrm{C}$, were the coded values of the independent variables (temperature, pressure and lactosemaltodetrin concentration, respectively). The analysis of variance (ANOVA) was performed with a confidence level of $95 \%(\mathrm{p}<0.05)$ with Modde 7.0 software.

Table 1 - Experimental drying conditions for spray drying of passion fruit juice.

\begin{tabular}{ccccc}
$\begin{array}{c}\text { Experiment } \\
\text { number }\end{array}$ & Run order & $\begin{array}{c}\text { Inlet air } \\
\text { temperature }\left({ }^{\circ} \mathbf{C}\right)\end{array}$ & $\begin{array}{c}\text { Air pressure } \\
(\mathbf{M P a})\end{array}$ & $\begin{array}{c}\text { Lactose:Maltodextrin } \\
\text { \% }(\mathbf{w} / \mathbf{v})\end{array}$ \\
\hline 1 & 5 & 180 & 0.1 & $8: 5$ \\
2 & 4 & 180 & 0.2 & $8: 5$ \\
3 & 22 & 185 & 0.15 & $8: 5$ \\
4 & 23 & 190 & 0.1 & $8: 5$ \\
5 & 14 & 190 & 0.2 & $8: 5$ \\
6 & 25 & 185 & 0.1 & $10: 5$ \\
7 & 9 & 190 & 0.15 & $10: 5$ \\
8 & 15 & 180 & 0.1 & $12: 5$ \\
9 & 13 & 180 & 0.2 & $12: 5$ \\
10 & 11 & 190 & 0.1 & $12: 5$ \\
11 & 12 & 190 & 0.2 & $12: 5$ \\
12 & 16 & 190 & 0.15 & $12: 5$ \\
13 & 2 & 190 & 0.15 & $12: 5$ \\
14 & 7 & 180 & 0.1 & $8: 5$ \\
15 & 10 & 180 & 0.2 & $8: 5$ \\
16 & 24 & 185 & 0.15 & $8: 5$ \\
17 & 26 & 190 & 0.1 & $8: 5$ \\
18 & 17 & 190 & 0.2 & $8: 5$ \\
21 & 18 & 185 & 0.1 & $10: 5$ \\
21 & 1 & 190 & 0.15 & $10: 5$ \\
26 & 3 & 180 & 0.1 & $12: 5$ \\
& 6 & 180 & 0.2 & $12: 5$
\end{tabular}




\section{RESULTS AND DISCUSSION}

The experimental values of the moisture content, hygroscopicity and vitamin $\mathrm{C}$ retention of the powder prepared with the lactose-maltodextrin blends are given in Table 2. These values were the means of three measurements. Results showed that the moisture content varied from 2.37 to $9.40 \%$; this variation was in the desired range of the quality parameters for a powder to be considered a dry product and was similar to that reported for the other food powders (Bhandari and Howes, 1999; Rodriguez-Hernández, et al., 2005). Table 2 also shows how the hygroscopicity varied from 17.39 to $35.38 \%$. These values were two or three times higher than the reported ones for the vacuum dried mango powder (Jaya and Das, 2004). The hygroscopicity can be defined as the ability of a food to absorb the moisture from a high relative humidity environment and has been related either to the porosity of the powder (Nadeau and Puiggali, 1995) or the amorphous glassy state of the sugars present in the food (Roos, 2002). From these results, it could be assumed that the lactose and fructose (main monosaccharide of this juice) were in an amorphous state, which was not stable in the normal humidity. This would explain why in the present study the powder was more hygroscopic. Data on the vitamin $\mathrm{C}$ retention showed that this vitamin was very sensitive to heat, since the retained percentage varied from 39.73 to $56.89 \%$ (Table 2).

Table 2 - Quality parameters of passion fruit juice powder prepared with lactose-maltodextrin blends as the support material.

\begin{tabular}{|c|c|c|c|}
\hline Experiment No & $\begin{array}{c}\text { Moisture content } \\
(\%)\end{array}$ & $\begin{array}{c}\text { Hygroscopicity } \\
(\%)\end{array}$ & $\begin{array}{c}\text { Vitamin C retention } \\
(\%) \\
\end{array}$ \\
\hline 1 & $9.40 \pm 0.34$ & $35.38 \pm 0.72$ & $43.28 \pm 1.02$ \\
\hline 2 & $9.10 \pm 0.98$ & $27.62 \pm 1.38$ & $53.38 \pm 1.01$ \\
\hline 3 & $7.14 \pm 0.86$ & $25.26 \pm 0.84$ & $44.81 \pm 4.23$ \\
\hline 4 & $5.66 \pm 0.77$ & $29.59 \pm 2.90$ & $49.30 \pm 2.12$ \\
\hline 5 & $6.66 \pm 0.71$ & $25.68 \pm 0.80$ & $46.12 \pm 1.00^{\mathrm{a}}$ \\
\hline 6 & $5.68 \pm 0.95$ & $32.78 \pm 0.47^{\mathrm{a}}$ & $45.81 \pm 3.56$ \\
\hline 7 & $6.08 \pm 0.57$ & $19.74 \pm 0.03$ & $49.80 \pm 1.42$ \\
\hline 8 & $3.91 \pm 0.69$ & $18.00 \pm 0.05$ & $40.44 \pm 1.00$ \\
\hline 9 & $2.67 \pm 0.28$ & $17.39 \pm 0.03$ & $46.83 \pm 4.01$ \\
\hline 10 & $3.17 \pm 0.04$ & $19.94 \pm 0.16$ & $41.86 \pm 1.03$ \\
\hline 11 & $6.10 \pm 0.63$ & $22.00 \pm 0.30$ & $47.54 \pm 1.01$ \\
\hline 12 & $2.37 \pm 0.34$ & $20.74 \pm 0.12$ & $43.03 \pm 1.06$ \\
\hline 13 & $5.35 \pm 0.55$ & $21.11 \pm 0.33$ & $41.70 \pm 1.01$ \\
\hline 14 & $9.16 \pm 0.56$ & $34.79 \pm 1.24$ & $44.93 \pm 2.16$ \\
\hline 15 & $8.72 \pm 0.04$ & $28.90 \pm 1.00$ & $56.89 \pm 2.01$ \\
\hline 16 & $6.94 \pm 0.03$ & $24.75 \pm 0.29$ & $47.80 \pm 2.99$ \\
\hline 17 & $3.87 \pm 0.89$ & $21.01 \pm 0.01$ & $44.40 \pm 3.11$ \\
\hline 18 & $4.74 \pm 0.13$ & $19.38 \pm 1.72$ & $50.80 \pm 0.01$ \\
\hline 19 & $2.99 \pm 0.52$ & $21.59 \pm 0.28$ & $49.29 \pm 2.11$ \\
\hline 20 & $6.81 \pm 0.56$ & $27.05 \pm 0.20$ & $49.46 \pm 0.97$ \\
\hline 21 & $4.18 \pm 0.37$ & $22.14 \pm 0.34$ & $42.10 \pm 2.17$ \\
\hline 22 & $4.43 \pm 0.72$ & $20.88 \pm 0.08$ & $45.41 \pm 1.42$ \\
\hline 23 & $3.21 \pm 0.08$ & $23.33 \pm 0.06$ & $47.80 \pm 2.99$ \\
\hline 24 & $4.56 \pm 0.13$ & $22.80 \pm 0.01$ & $40.33 \pm 0.30$ \\
\hline 25 & $3.18 \pm 0.91$ & $25.32 \pm 0.29$ & $39.73 \pm 1.42$ \\
\hline 26 & $4.37 \pm 0.39$ & $26.11 \pm 0.94$ & $41.83 \pm 0.38$ \\
\hline
\end{tabular}

${ }^{\mathrm{a}}$ Outlier values were not considered in this study.

The experimental data of Table 2 was subjected to the statistical analysis using a polynomial model (Eq. 2). The regression coefficients and variance analysis describing the effect of the independent variables on the properties of the powder are shown in Table 3. Looking at the values of $p(t)$, it was clear that the moisture content was linearly affected in the first place by the lactose- 
maltodextrin concentration, secondly by a temperature-concentration interaction and in the least degree, by the temperature itself. The quadratic effects of the temperature, pressure, and concentration were not significant. With respect to the hygroscopicity, this was mainly influenced by the lactose-maltodextrin concentration and the $\mathrm{T}^{*} \mathrm{C}$ interaction (Table 3 ).

Table 3 - Regression coefficients (coded variables) and variance analysis of experimental results shown in Table 2 $(\mathrm{p}<0.05)$.

\begin{tabular}{|c|c|c|c|c|c|c|c|c|c|c|}
\hline Response & $\beta_{0}$ & $\beta 1$ & $\beta_{2}$ & $\beta 3$ & $\beta 4$ & $\beta 5$ & $\beta 6$ & $\beta_{7}$ & $\beta 8$ & $\beta 9$ \\
\hline $\mathrm{MC}$ & 5.6485 & -0.9155 & 0.3418 & -1.7554 & 1.2227 & -0.4824 & -0.8531 & 0.49187 & 0.95955 & 0.13437 \\
\hline$p(\mathrm{t})$ & $5.88 \mathrm{e}-7$ & 0.003859 & 0.22578 & $2.997 \mathrm{e}-6$ & 0.10695 & 0.39024 & 0.22598 & 0.091255 & 0.002215 & 0.63017 \\
\hline $\mathrm{H}$ & 21.1556 & -1.3195 & -1.2368 & -3.4435 & 3.6879 & -1.0605 & 0.53496 & 0.71937 & 2.5754 & 1.17813 \\
\hline$p(\mathrm{t})$ & $8.82 \mathrm{e}-8$ & 0.0910812 & 0.111228 & 0.0001456 & 0.10144 & 0.5069 & 0.78902 & 0.34421 & 0.002565 & 0.130547 \\
\hline $\mathrm{VC}$ & 48.1274 & -0.0311 & 2.44463 & -2.75161 & 1.20578 & 2.19514 & -4.90194 & -1.56637 & 0.25188 & -1.41488 \\
\hline$p(\mathrm{t})$ & $4.3 e-15$ & 0.9607 & 0.00117 & 0.000193 & 0.44721 & 0.08646 & 0.004412 & 0.02353 & 0.6769 & 0.03789 \\
\hline \multicolumn{2}{|l|}{ Response } & \multicolumn{2}{|l|}{ Source } & DF & \multicolumn{2}{|l|}{ SS } & MS & \multicolumn{2}{|l|}{$\mathbf{F}$} & $p(F)$ \\
\hline \multirow[t]{3}{*}{$\mathrm{MC}$} & \multicolumn{3}{|c|}{ Total corrected } & 25 & 111.659 & & 4.46637 & \multirow{3}{*}{\multicolumn{2}{|c|}{8.57035}} & \\
\hline & & egression & & 9 & 92.4766 & & 10.2752 & & & 0.000 \\
\hline & & esidual & & 16 & 19.1827 & & 1.19892 & & & \\
\hline \multirow[t]{3}{*}{$\mathrm{H}$} & \multicolumn{3}{|c|}{ Total corrected } & 24 & 523.229 & & 21.8012 & \multirow{3}{*}{\multicolumn{2}{|c|}{5.03119}} & \\
\hline & & egression & & 9 & 393.03 & & 43.6701 & & & 0.003 \\
\hline & & esidual & & 15 & 130.198 & & 8.67987 & & & \\
\hline \multirow[t]{3}{*}{$\mathrm{VC}$} & \multicolumn{3}{|c|}{ Total corrected } & 24 & 446.012 & & 18.5838 & \multirow{3}{*}{\multicolumn{2}{|c|}{7.2166}} & \\
\hline & & egression & & 9 & 362.336 & & 40.2591 & & & 0.000 \\
\hline & & esidual & & 15 & 83.6801 & & 5.57867 & & & \\
\hline
\end{tabular}

Note: The bold character indicates that the corresponding parameter had a significant effect on the properties evaluated.

As for vitamin $\mathrm{C}$ retention, it was affected quadratic and linearly by the concentration, air pressure, and the $\mathrm{T} * \mathrm{P}$ and $\mathrm{P} * \mathrm{C}$ interactions. Table 3 also showed that the most important interaction for the moisture content and hygroscopicity was the $\mathrm{T}^{*} \mathrm{C}$ while for the vitamin $\mathrm{C}$ retention was the $\mathrm{T}^{*} \mathrm{P}$.

The response surface plots were generated for the moisture content (Fig.1) and hygroscopicity (Fig. 2), making the inlet temperature and concentration change independently. A similar graph was obtained for the vitamin $\mathrm{C}$ retention (Fig. 3), being the temperature and compressor air pressure the independent variables. The models interpreted data variability with a determination coefficient higher than 0.75 given in equations (3)-(5) with the uncoded variables:

Model for moisture content $(M C)$ :

$$
\begin{aligned}
& M C=1929.7-19.53 T-312.69 P-14.56 C+0.049 T^{2} \\
& -192.96 P^{2}-0.213 C^{2}+1.96 T P+0.096 T C+1.34 P C \\
& R^{2}=0.828
\end{aligned}
$$

Model for hygroscopicity $(H)$ :

$$
\begin{aligned}
& H=5717.5-57.85 T-547.62 P-53.81 C+0.148 T^{2} \\
& -424.2 P^{2}+0.134 C^{2}+2.87 T P+0.258 T C+11.78 P C \\
& R^{2}=0.751 \\
& \text { Model for vitamin C retention }(V C): \\
& V C=1455.13-17.163 T+1086.08 P+20.59 C+0.048 T^{2} \\
& +878.05 P^{2}-1.225 C^{2}-6.26 T P+0.0251 T C-14.15 P C \\
& R^{2}=0.812
\end{aligned}
$$

In all the cases, there was a good agreement between the experimental and predicted values. The shapes in Figures 1 and Figure 2 indicated that the moisture content and the hygroscopicity of the powder decreased significantly with the higher concentrations and higher temperatures. These observations made it clear that the best quality of the product was achieved in the temperature range of 188 to $190{ }^{\circ} \mathrm{C}$ with a concentration of $12: 5 \%$ of the lactose-maltodextrin. 


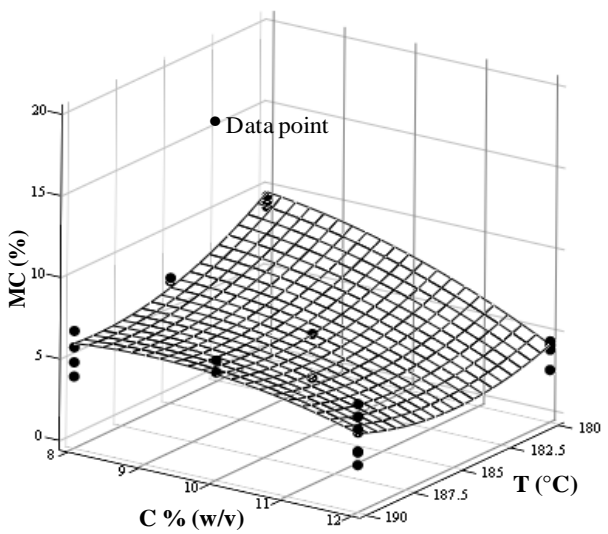

Figure 1 - Effect of the inlet air temperature and the lactose-maltodextrin concentration on the moisture content of the powder.

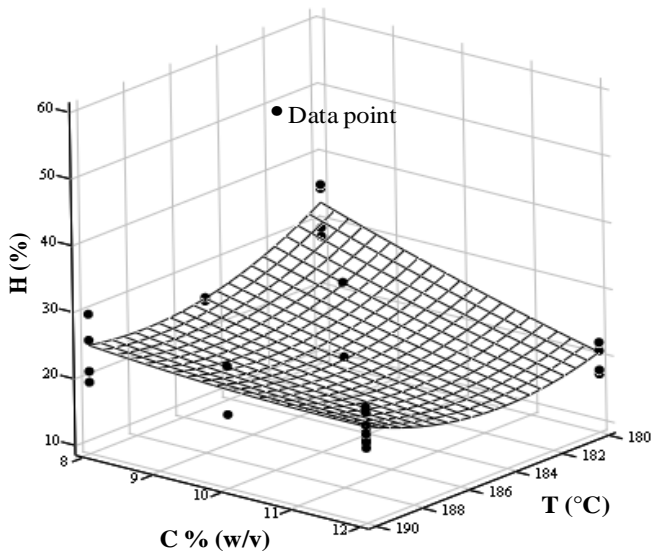

Figure 2 - Effect of the inlet air temperature and the lactose-maltodextrin concentration on the hygroscopicity of the powder.

Although the pressure did not have a significant effect, it was also observed that the moisture content and hygroscopicity decreased slightly with the pressure (results not shown). These results agreed i.e. with those of other authors (Masters, 1991b), the higher drying air temperatures and higher pressure usually resulted in faster drying, thus generating the products with lower moisture content. The pressure has an enormous influence on the particle size and the particle diameter is inversely proportional to the pressure. Therefore, the drop size establishes the heat transfer surface available, and thus, the drying rate. In the particles smaller in diameter, the water within would migrate a shorter distance to reach the surface and the droplet consequently will dry faster. As mentioned previously, the hygroscopicity also depended on the size of powder pores (Nadeau and Puiggali, 1995). The powders with more compact constitution were obtained at high pressures, thereby exhibiting less hygroscopicity.

The effect of the air pressure and temperature on the vitamin $\mathrm{C}$ retention during the spray drying of the passion fruit juice is shown in Figure 3. The vitamin $\mathrm{C}$ retention increased as the temperature was lowered and pressure was raised, reaching its maximum value at $180{ }^{\circ} \mathrm{C}$ and $0.2 \mathrm{MPa}$ and the retention was higher at 10:5 \% (w/v) concentration of the lactose-maltodextrin. Several authors (Nicoleti et al., 2004; Ramallo and 
Mascheroni, 2004; Pirone et al., 2005) have reported that the degradation of the ascorbic acid during the drying is influenced by the moisture content, oxygen, $\mathrm{pH}$, and light, but especially by the temperature. However, the way in which the pressure influences the vitamin $\mathrm{C}$ degradation during the spray-drying process has not been clearly established. Rodriguez-Hernández et al.,
(2005) reported that the vitamin $\mathrm{C}$ was better retained in the spray-dried powder of cactus pear processed at low pressures, while the opposite effect was observed for the experiments done at $0.1 \mathrm{MPa}$ in this work. Other factors such as the different chemical composition and $\mathrm{pH}$ of the two foods could explain the difference in behavior.

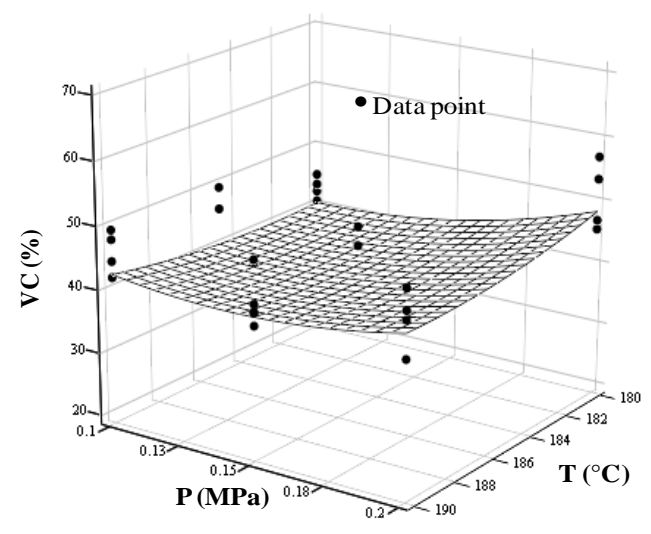

Figure 3 - Effect of the inlet air temperature and the air pressure on the vitamin $\mathrm{C}$ retention of the powder.

\section{CONCLUSIONS}

The results of this work indicated that the combination of the lactose and $10 \mathrm{DE}$ maltodextrin worked effectively as a carrier agent for the spraydrying of the passion fruit juice. Low amounts of the lactose-maltodextrin such as 8:5, 10:5, 12:5\% $(\mathrm{w} / \mathrm{v})$ could be used to achieve the drying and diminish the stickiness in the drying chamber.

However, due to the utilization of lactose, the powder obtained was highly hygroscopic. Response surface studies showed that the lowest values of the moisture content and hygroscopicity were reached in the temperature range $188-190{ }^{\circ} \mathrm{C}$ with $12: 5 \%(\mathrm{w} / \mathrm{v})$ of the lactose-maltodextrin concentration; the best vitamin $\mathrm{C}$ retention was obtained at $180{ }^{\circ} \mathrm{C}$ and $0.2 \mathrm{MPa}$ with $10: 5 \%(\mathrm{w} / \mathrm{v})$ of the carrier agent.

\section{ACKNOWLEDGEMENTS}

The authors wish to acknowledge the financial support from the International Foundation for
Science (Research Grant Agreement No. E/33471) and would also like to thank O. BeltránGuevara for the revision of the English version.

\section{RESUMO}

O objectivo deste estudo foi a avaliação da efectividade das misturas en diferentes níveis de lactose-maltodextrina $(8: 5,10: 5,12: 5 \%$ w/v) durante a pulverização do sumo de maracujá. A secagem foi feita em um atomizador de laboratório de pulverização (modelo Pulvis GB 22) com 2 entradas de temperatura de ar $\left(180\right.$ e $\left.190{ }^{\circ} \mathrm{C}\right)$, e 2 compressores de pressão de ar $(0.10$ e $0.20 \mathrm{MPa})$. $\mathrm{O}$ índice da mistura, higroscopicidade e retenção de vitamina $\mathrm{C}$ foram avaliados no pó obtido. As curvas de superfície de resposta $(p<0.05)$ mostram que os valores mais baixos do índice da mistura e higroscopicidade foram alcançados no intervalo de temperatura de $188-190{ }^{\circ} \mathrm{C}$ e com uma concentração de $12: 5 \%$ w/v de lactosemaltodextrina; o melhor nível de retenção de vitamina $\mathrm{C}$ ocorreu a $180{ }^{\circ} \mathrm{C}$ e $0.2 \mathrm{MPa}$. 


\section{REFERENCES}

AOAC (1990), Official Methods of Analysis. $15^{\text {th }}$ Ed. Association of Official Analytical Chemists. Washington, D.C.

Barbosa-Cánovas, G. V.; Ortega-Rivas, E.; Juliano, P.; Yan, H. (2005), Drying. In Food Powders-Physical Properties, Processing and Functionality, First Ed.; Kluwer Academic/Plenum Publishers, New York, pp. 271-304.

Bhandari, B. R.; Howes, T. (1999), Implication of glass transition for the drying and stability of dried foods. Journal of Food Engineering, 40, 71-79.

Brat, P.; Olle, D.; Reynes, M.; Cogat, P. O.; Brillouet, J.M. (2001), Preparation of passion fruit puree by flash vacuum-expansion. Journal of Food Science, 66 (4), 542-547.

Cai, Y. Z.; Corke, H. (2000), Production and properties of spray-dried Amaranthus Betacyanin pigments. Journal of Food Science, 65 (6), 1248-1252.

Cardoso-Pereira, C.; Meira-Rufino, J.; Habert, C.A.; Nobrega, R.; Correia-Cabral, L. M.; Piacsek-Borge, C. (2002), Membrane for processing tropical fruit juice. Desalination, 148, 57-60.

Chan, H. T.; Chang, T. S. K.; Chenchin, E. (1972), Nonvolatile acids of passion fruits juice. Journal Agriculture Food Chemistry, 20 (1), 110-112.

Flores-Novelo, G. (2000), Extracción enzimática del jugo de maracuyá (Passiflora edulis v. flavicarpa). Master Thesis, Instituto Tecnológico de Mérida, Mérida Yucatán, México.

Goula, A.M.; Adamopoulos, K.G. (2005), Spray drying of tomato pulp in dehumidified air. I-The effect on product recovery. Journal of Food Engineering, 66 (1), 25-34.

Jaya, S.; Das, H. (2004), Effect of maltodextrin, glycerol monostearate and tricalcium phosphate on vacuum dried powder properties. Journal of Food Engineering, 63, 125-134.

Krishnan, S.; Bhosale, R.; Singhal, R. S. (2005), Microencapsulation of cardamom oleoresin: Evaluation of blends of gum Arabic, maltodextrin and a modified starch as wall materials. Carbohydrates Polymers, 61, 95-102.

Masters, K. (1991)a, Applications in the food industry. In Spray Drying Handbook, Fifth Ed.; Longman Scientific and Technical, New York, pp. 587-638.

Masters, K. (1991)b, Drying of droplets/sprays. In Spray Drying Handbook, Fifth Ed.; Longman Scientific and Technical, New York, pp. 309-351.

Mermelstein, N.H. (2001), Spray drying. Food Technology, 55 (4), 92-96.

Nadeau, J.P.; Puiggali, J.R. (1995), Séchage: des processus physiques aux procédés industriels. $1^{\text {st }}$ Ed.; Technique et Documentation-Lavoisier, Paris Cedex, $307 \mathrm{p}$.

Nicoleti, F.; Silveira-Junior, V.; Telis-Romero, J.; Telis, V. R. N. (2004), Ascorbic degradation during convective drying of persimmons with fixed temperature inside the fruit. Paper presented at the $14^{\text {th }}$ International Drying Symposium, 22-25 August, São Paulo, Brazil, Vol. C, 1836-1843.

Pirone, B.N.; Ochoa, M.R.; Kesseler, A.G.; De Michelis, A. (2005), Evolución de la concentración de ácido ascórbico durante el proceso de deshidratación de frutos de la rosa mosqueta (Rosa eglanteria L.). Revista de Investigaciones Agropecuarias, 31(1), 85-98.

Ramallo, L.A.; Mascheroni, R. (2004), Prediction and determination of ascorbic acid content during pineapple drying. Paper presented at the $14^{\text {th }}$ International Drying Symposium, 22-25 August, São Paulo, Brazil, Vol. C, 1984-1991.

Rodriguez-Hernández, G.R.; González-García, R.; Abud-Archila, M.A.; Grajales-Lagunes, A.; RuizCabrera, M.A. (2005), Spray drying of cactus pear juice: Effect on the physicochemical properties of powder and reconstituted product. Drying Technology, 23, 955-973.

Roos, Y. H. (2002), Importance of glass transition and water activity to spray drying and stability of dairy powders. Lait, 82, 475-484.

Schwentesius, R.; Gómez-Cruz, M.A. (1998), La oferta nacional del maracuyá debe estabilizarse para permitir consolidar el mercado de sus derivados en México. Bebidas Mexicanas, 7 (2), 14-16.

Truong, V.; Bhandari, B.R.; Howes, T. (2005), Optimization of co-current spray drying process of sugar-rich foods. Part I-Moisture and glass transition temperature profile during drying. Journal of Food Engineering, 71 (1), 55-65.

Vaillant, F.; Jeanton, E.; Dornier, M.; O’brien, G. M.; Reynes, M. Decloux, M. (2001), Concentration of passion fruit juice on an industrial pilot scale using osmotic evaporation. Journal of Food Engineering, 47, 195-202.

Vera, E.; Dornier, M.; Ruales, J. Vaillant, F.; Reynes, M. (2003), Comparison between different ion exchange resins for the deacidification of passion fruit juice. Journal of Food Engineering, 57 (2), 199207.

Received: December 21, 2006; Revised: August 20, 2007; Accepted: August 18, 2008 